НАУКОВИЙ ВІСНИК

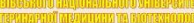

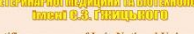

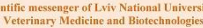
Tin 11 IIIIN - The
Науковий вісник Львівського національного університету ветеринарної медицини та біотехнологій імені С.3. Гжицького. Серія: Харчові технології

\author{
Scientific Messenger of Lviv National University \\ of Veterinary Medicine and Biotechnologies.
}

Series: Food Technologies

UDC 619.782:637.146

\title{
The influence of the introduction of rice bran on fermented milk drink
}

\author{
M. Samilyk ${ }^{1}$, X. Qin ${ }^{2}$, Y. Luo ${ }^{2}$ \\ ${ }^{I}$ Sumy National Agrarian University, Sumy, Ukraine \\ ${ }^{2}$ School of Food and Bioengineering, Hezhou University, Hezhou, China
}

Article info

Received 30.04.2021

Received in revised form 01.06 .2021

Accepted 02.06.2021

Sumy National Agrarian University Herasyma Kondratieva str., 160,

Sumy, 40021, Ukraine.

Tel: $+38-066-378-67-39$

E-mail: maryna.samilyk@snau.edu.ua

School of Food and

Bioengineering, Hezhou University,

Xihuan str., 18, Hezhou, 542899.

China.

Tel.: +86-157-784-722-20

E-mail:1175608765@qq.com
Samilyk, M., Qin, X., \& Luo, Y. (2021). The influence of the introduction of rice bran on fermented milk drink. Scientific Messenger of Lviv National University of Veterinary Medicine and Biotechnologies. Series: Food Technologies, 23(96), 39-45. doi: 10.32718/nvlvet-f9608

Rice bran is an agro-industrial waste with excellent nutritional value and a considerable content of bioactive compounds. Biotransformation processes by fermented milk drink fermentation increase the interest in obtaining products from agro-industrial wastes with good biological properties. The viability of introducing rice bran $(R B)$ into fermented milk drinks to improve the structural stability and sensory was studied. Fermented milk drink supplemented with 0, $0.1 \%, 0.3 \%, 0.5 \%, 0.7 \%$ amount of RB were studied. Samples were stored for 28 days at $4 \pm 1{ }^{\circ}$ C. Samples composition was studied, Physicochemical properties (total titratable acidity, apparent viscosity, and $\mathrm{pH}$ ) and consumer's acceptability of fermented milk drinks were determined at 0,7 th, 14 th, 21th and 28th days of storage. Studies showed that rice bran wan rich in dietary fiber $(28.57 \%)$, fat $(21.56 \%)$, and protein $(11.18 \%)$. The introduction of RB showed a significant influence on these parameters $(P<0.05)$. The introduction of $R B$ would significantly improve the value of titratable acidity and apparent viscosity and decrease $\mathrm{pH}$ value. The more rice bran was added, the higher the values of titratable acidity and apparent viscosity were. The lower the $\mathrm{pH}$ value was, which could shorten the fermentation time, improve the texture stability, save production cost. The storage period could significantly influence the value of titratable acidity, $\mathrm{pH}$, and apparent viscosity. The longer the storage period was, the higher the titratable acidity values were, the lower the $\mathrm{pH}$ value was caused by the post-fermentation of fermented milk drink. The apparent viscosity showed a trend of rising first and falling then during the storage period. The introduction of RB could significantly influence the sensory characteristic (color, consisten$c y$, sour, and texture). The introduction of $R B$ would lead to whey separation and rough structure. Fermented milk drink supplemented with $0.1 \%$ RB showed higher sensory acceptance. The best shelf life of the sample is 14 days, during which time fermented milk drink was of the best quality. RB is a kind of raw material with bright application prospects in a fermented milk drink.

Key words: fermented milk drink, rice bran, agro-industrial waste, viscosity, sensory.

\section{Вплив введення рисових висівок на кисломолочний напій}

\author{
М. Самілик ${ }^{1}$, С. Цинь ${ }^{2}$, Я. Ло ${ }^{2}$ \\ ${ }^{1}$ Сумський національний аграрний університет, м. Суми, Украӥна \\ ${ }^{2}$ Школа харчування та біоінженерії, Університет Хечжоу, Хечжоу, Китай
}

Рисові висівки - це агропромислові відходи з високою харчовою иінністю та значним вмістом біоактивних сполук. Процеси біотрансформачії иляхом бродіння кисломолочних напоїв підвищують інтерес до отримання продуктів з агропромислових відходів з добрими біологічними властивостями. Досліджено життєздатність введення рисових висівок (РВ) у кисломолочний напій для поліпшення структурної стабільності та чутливості. Було досліджено кисломолочний напій з добавкою РВ 0,1, 0,1 \%, 0,3 \%, 0,5\%, 0,7 \%. Зразки зберігали 28 днів при температурі $4 \pm 1{ }^{\circ}$ С. Досліджено склад зразків, вивчено фізико-хімічні властивості (загальну титровану кислотність, в'язкість та рН) та можливість споживання кисломолочних напоїв на 0, 7, 14, 21 та 28 день зберігання. Дослідження показало, щуо рисові висівки багаті харчовими волокнами (28,57 \%), жиром (21,56 \%) та білком (11,18 \%). Введення РВ показало значний вплив на ці параметри (P < 0,05). При додаванні більшої кількості рисових висівок вищими були значення титрованої кислотності та видимої в'язкості, нижчим - значення рН, щуо може скоротити час бродіння, поліпшити стабільність текстури та заощадити витрати на виробництво. Період зберігання може істотно вплинути на значення титро- 
ваної кислотності, рН та видимої в'язкості. При збільшенні періоду зберігання підвишувалося значення титрованої кислотності, знижувався рН. Це спричинено постзброджуванням кисломолочного напою. В'язкість спочатку зростала, а потім знижувалася протягом періоду зберігання. Введення РВ може суттєво вплинути на сенсорні характеристики (колір, консистенцію та текстуру). Введення РВ призвело до поділу сироватки та грубої структури. Кисломолочний напій, доповнений 0,1 \% РВ, продемонстрував більш високе сприйняття сенсорами. Встановлено найкращиий термін зберігання зразка - 14 днів, протягом яких зберігається якість кисломолочного напою. Рисові висівки - це різновид сировини з яскравою перспективою застосування у кисломолочних напоях.

Ключові слова: кисломолочний напій, рисові висівки, агропромислові відходи, в 'язкість, сенсорні властивостві.

\section{Introduction}

Fermented milk drink is a kind of fermented beverage, which is traditionally prepared by inoculation of raw milk with fermented milk drink grains. Fermented milk drink is regarded as a nutritious and healthy drink. Some results indicate that fermented milk drink and its constituents have pro-healthy properties that positively affect immune and gastrointestinal system (Iraporda et al., 2014). In certain studies it helped with lactose intolerance (Leite et al., 2015), affected the cholesterol metabolism (Kim et al., 2017), revealed therapeutic activity against colon carcinogens (Ahmed et al., 2013). It was the source of some vitamins (Wyk et al., 2011). Besides, fermented milk drink cultures can be applied to promote food safety by inhibiting coliforms and numerous pathogens (Wyk et al., 2011).

Almost all types of dairy products can combine with different plant components. Many scientists are trying to create healthy food by considering natural plant components (Zaharova, 2014). However, the introduction of some kinds of plant components would lead to decrease of viscosity, separation of whey, deterioration of the taste of dairy products. These negative reactions cause an increase in the amounts of flavors and stabilizers. For this reason, the urgent task of research on plant-based fermented milk drink is to develop formulations of dairy products that have natural fillers, but have no negative effects on fermented milk drink.

$\mathrm{RB}$ is a by-product of rice milling industry and constitutes around $10 \%$ of the total weight of rough rice (Hu et al., 1996). It is primarily composed of aleurone, pericarp, sub aleurone layer and germ. Each year $90 \%$ of the rice bran produced in the world is utilized cheaply as a feed stock for cattle and poultry and the remainder is used for extraction of rice bran oil (Zullaikah et al., 2009). Protein in RB is a kind of high quality protein, it has appropriate amino acid composition and high biological potency, the lysine content reaches as high as $5.8 \mathrm{~g} / 100 \mathrm{~g}$. Oil in RB can help to lower blood pressure and improve the lipid profile in mild-to-moderate hypertensive patients (Devarajan et al., 2016; Perez-Ternero et al., 2017), prevent colon cancer (Li et al., 2011). Fiber in RB can help to keep the health of gut. In recent days, the applications of RB as food were focused on: the extraction of protein (Phongthai et al., 2016), fiber (Jia et al., 2019), oil (Soares et al., 2016; Trevisani Juchen et al., 2019), vitamin B (Chen et al., 2011) and other biological components (Tabaraki \& Nateghi, 2011); the stabilization of rice bran (Patil et al., 2016); the supplement of RB into bread
(Tuncel et al., 2014), sausage (Choi et al., 2010), drinks (Prestes et al., 2019). Few researches were about the supplement of RB in fermented milk.

This study aimed to evaluate physicochemical properties (total titratable acidity, apparent viscosity and $\mathrm{pH}$ ) and consumer's acceptability of fermented milk drink enriched with RB.

\section{Materials and methods}

Fermented milk drink grains were obtained from private households in Tibet, China. Cow milk was supplied from Mengniu Dairy Group Co, Neimenggu, China. All chemicals were of analytical grade. RB were procured from local market (Xingtai, Hebei, China). RB was homogenized by sieving through fine screen (200 mesh). RB was steam sterilized at $121{ }^{\circ} \mathrm{C}$ for 15 minutes before used.

Fermented milk drink was used as start culture at a ratio of $10 \%(\mathrm{~V} / \mathrm{V})$. Five raw materials formulas were investigated: cow milk added with 0 (control), $0.1 \%$ (A), $0.3 \%$ (B), $0.5 \%$ (C), $0.7 \%$ (D) amount of RB. All kinds of mixture were fermented at $28{ }^{\circ} \mathrm{C}$ for about $22 \mathrm{~h}$ until $\mathrm{pH}$ reached to 4.7 , fermented milk drink samples were stored at $4{ }^{\circ} \mathrm{C}$ for 28 days.

The content of protein, dietary fiber, fat for RB were studied. Fat contents were confirmed by Soxhlet extraction method (GB 5009.6, 2016); The protein content was determined by Kjeldahl method (ISO, 2014), A multiplication factor of 5.95 was used to convert nitrogen percentage to protein percentage. Dietary fiber was measured according to (AOAC, 2000).

Physicochemical indexes including $\mathrm{pH}$, total titratable acidity, apparent viscosity, water-holding capacity, color measurements and nuclear magnetic resonance were studied every 7 days for 28 days for all samples. The $\mathrm{pH}$ value was determined by a $\mathrm{pH}$ meter (METTLER TOLEDO LE438, Switzerland). The titratable acidity was measured by titrating $10 \mathrm{~g}$ of sample with $0.1 \mathrm{~N} \mathrm{NaOH}$ using phenolphthalein indicator (GB5009. 239-2016). The apparent viscosity of the samples was measured with a digital viscometer (NDJ-8S, Shanghai, China).

Sensory evaluation was conducted using 40 untrained panelists (25 women and 15 men, age 20-36). Panelists examined and tasted the samples and recorded their perceptions by making marks according to scoring criteria. They examined color, consistency, sour, texture and flavor. During sensory analyses, panelists were provided with plain cracker sticks and water, instructed to clear their mouth between tastings. The scoring criteria was showed in table 1 . 
Table 1

Scoring criteria for fermented milk drink

\begin{tabular}{|c|c|c|}
\hline Items & Standard for evaluation & Score \\
\hline \multirow{3}{*}{ color } & Uniform color and slight yellow & $8-9$ \\
\hline & slight delamination, slight yellow & $7-8$ \\
\hline & delamination, uneven color & $<7$ \\
\hline \multirow{4}{*}{ consistency } & Moderate consistency and heavy palate & $8-9$ \\
\hline & slightly thin consistency & $7-8$ \\
\hline & thin or heavy consistency & $5-7$ \\
\hline & very thin or heavy consistency & $<5$ \\
\hline \multirow{4}{*}{ sour } & Moderate sour taste, without astringency & $8-9$ \\
\hline & slight or heavy sour taste, without astringency & $7-8$ \\
\hline & slight sour taste and astringency & $6-7$ \\
\hline & very slight or heavy sour taste, and heavy astringency & $<6$ \\
\hline \multirow{4}{*}{ texture } & uniform and smooth texture, exquisite structure, without bubbles & $8-9$ \\
\hline & slightly uniform and smooth texture, slightly exquisite structure, without bubbles & $7-8$ \\
\hline & slightly rough texture, a small number of bubbles & $5-7$ \\
\hline & rough texture, more bubbles & $<5$ \\
\hline \multirow{4}{*}{ flavor } & intense flavor of rice and kefir & $8-9$ \\
\hline & moderate flavor of rice and kefir & $7-8$ \\
\hline & moderate flavor of kefir and slight flavor of rice & $5-7$ \\
\hline & moderate flavor of kefir and without flavor of rice & $<5$ \\
\hline
\end{tabular}

All experiments were replicated in three flasks and the data are presented as the mean and standard error of three independent experiments. Tukey's multiple range test was used to determine the significant differences among mean values at the $\mathrm{P}=0.05$ level. Statistical analyses were carried out using the Data Processing System soft-ware (DPS version 7.05, SAS Institute, Inc., 2000).

\section{Results}

Table 2 showed the main components of RB, result showed that RB was rich in dietary fiber, the content was up to $28.57 \%$; The content of fat and protein were high ( $21.56 \%$ and $11.18 \%$ respectively), too. Its high content of dietary fiber and protein could play a good thickening effect on fermented milk drink.

Table 2

Chemical composition of RB ( $n=3, \pm S D)$

\begin{tabular}{cccccc}
\hline component & fat & protein & dietary fiber & ash & water \\
\hline content $(\%)$ & $21.56 \pm 0.21$ & $11.18 \pm 0.33$ & $28.57 \pm 1.98$ & $8.57 \pm 1.34$ & $9.77 \pm 0.07$ \\
\hline
\end{tabular}

* Values expressed as mean \pm standard deviation of duplicate samples.

The result of $\mathrm{pH}$ and titratable acidity of fermented milk drinks were showed in table 3 and figure 1,2.

The $\mathrm{pH}$ of the samples was ranged between 4.23 and 5.06. The titratable acidity was ranged between $70.02 \mathrm{~T}$ and 105.22 T. Addition of RB caused to the significant decrease of $\mathrm{pH}$ values and increase of the titratable acidity of fermented milk drinks $(\mathrm{P}<0.05)$. The results indicate that the more $\mathrm{RB}$ was added, the lower the $\mathrm{pH}$ were and the higher the titratable acidity were, $0.7 \%$ DSC added fermented milk drink samples had the lowest $\mathrm{pH}$ and the highest titratable acidity contents. It could be related to stimulation of lactic acid bacteria by fiber. Previous studies have also demonstrated that fermented milk drink as a probiotic (Guzel-Seydim et al., 2011; Chifiriuc et al., 2011) and dietary fiber had a potential prebiotic effect (Shah et al., 2020; Wu et al., 2020).

As expected, the storage period significantly affected the level of $\mathrm{pH}$ and acidity of samples $(\mathrm{P}<0.05)$. With the prolonging of storage period, the $\mathrm{pH}$ value of all samples decreased significantly $(\mathrm{P}<0.05)$, and the titration acidity increased significantly $(\mathrm{P}<0.05$ ), the change of $\mathrm{pH}$ value was more significant than that of titration acidity.

The appropriate titrated acidity of fermented milk drink was between $70 \mathrm{~T}$ and $95 \mathrm{~T}$, on the $28^{\text {th }}$ day of storage period, the titrated acidity of fermented milk drinks added with RB exceeds 95T, which showed that kefir added with RB was not suitable for further consumption on $28^{\text {th }}$ day. It is best to fermented milk drink added with RB within 21 days.

Table 4 and figure 3 presented the change of apparent viscosity of fermented milk drink in 28 days. Results showed that the introduction of RB could significantly improve the apparent viscosity of fermented milk drink ( $\mathrm{P}<0.05)$, the more RB was added, the higher the apparent viscosity was. The texture of kefir were affected by weak physical bonds, electrostatic and hydrophobic interactions, the introduction of RB could improve these interactions (Ertekin \& Guzel-Seydim, 2010). 


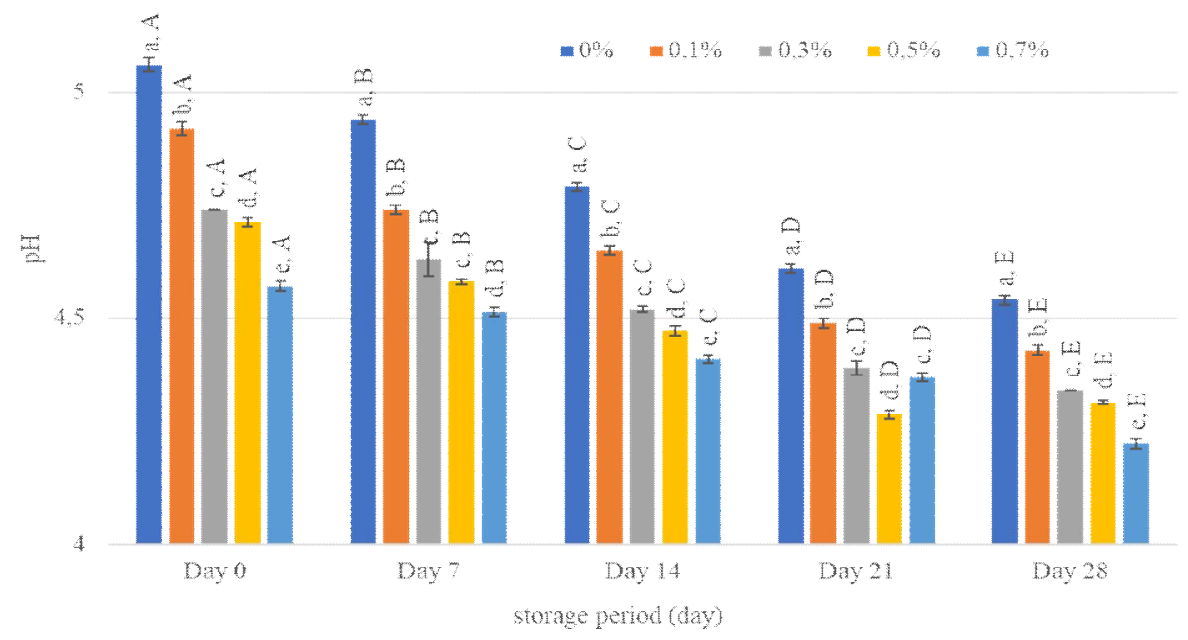

Fig. 1. $\mathrm{pH}$ of fermented milk drink samples during storage for 28 days $(\mathrm{n}=3, \pm \mathrm{SD})$

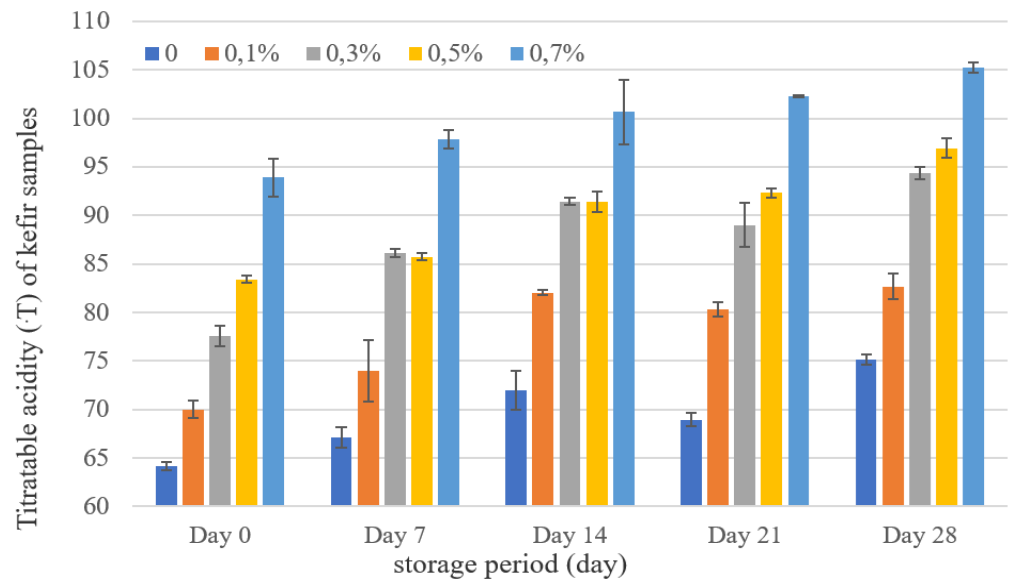

Fig. 2. Titratable acidity of fermented milk drink samples during storage for 28 days $(n=3, \pm S D)$

Table 3

$\mathrm{pH}$ and titratable acidity of fermented milk drink samples

\begin{tabular}{ccccccc}
\hline & Samples & Day 0 & Day 7 & Day 14 & Day 21 & Day 28 \\
\cline { 2 - 7 } & 0 & $5.06 \pm 0.02^{\mathrm{a}, \mathrm{A}}$ & $4.94 \pm 0.01^{\mathrm{a}, \mathrm{B}}$ & $4.79 \pm 0.00^{\mathrm{a}, \mathrm{C}}$ & $4.61 \pm 0.01^{\mathrm{a}, \mathrm{D}}$ & $4.54 \pm 0.01^{\mathrm{a}, \mathrm{E}}$ \\
$\mathrm{n} \mathrm{pH}$ & $0.1 \%$ & $4.92 \pm 0.00^{\mathrm{b}, \mathrm{A}}$ & $4.74 \pm 0.04^{\mathrm{b}, \mathrm{B}}$ & $4.65 \pm 0.01^{\mathrm{b}, \mathrm{C}}$ & $4.49 \pm 0.02^{\mathrm{b}, \mathrm{D}}$ & $4.43 \pm 0.02^{\mathrm{b}, \mathrm{E}}$ \\
& $0.3 \%$ & $4.74 \pm 0.01^{\mathrm{c}, \mathrm{A}}$ & $4.63 \pm 0.01^{\mathrm{c}, \mathrm{B}}$ & $4.52 \pm 0.01^{\mathrm{c}, \mathrm{C}}$ & $4.38 \pm 0.01^{\mathrm{c}, \mathrm{D}}$ & $4.34 \pm 0.00^{\mathrm{c}, \mathrm{E}}$ \\
& $0.5 \%$ & $4.71 \pm 0.00^{\mathrm{d}, \mathrm{A}}$ & $4.58 \pm 0.01^{\mathrm{c}, \mathrm{B}}$ & $4.47 \pm 0.01^{\mathrm{d}, \mathrm{C}}$ & $4.29 \pm 0.01^{\mathrm{d}, \mathrm{D}}$ & $4.31 \pm 0.01^{\mathrm{d}, \mathrm{E}}$ \\
& $0.7 \%$ & $4.57 \pm 0.00^{\mathrm{e}, \mathrm{A}}$ & $4.52 \pm 0.02^{\mathrm{d}, \mathrm{B}}$ & $4.41 \pm 0.01^{\mathrm{e}, \mathrm{C}}$ & $4.37 \pm 00^{\mathrm{c}, \mathrm{D}}$ & $4.23 \pm 0.01^{\mathrm{e}, \mathrm{E}}$ \\
\hline Titratable & $0.1 \%$ & $70.02 \pm 0.89^{\mathrm{d}, \mathrm{B}}$ & $74.01 \pm 3.16^{\mathrm{c}, \mathrm{B}}$ & $82.05 \pm 0.26^{\mathrm{c}, \mathrm{A}}$ & $80.30 \pm 0.72^{\mathrm{d}, \mathrm{A}}$ & $82.14 \pm 0.51^{\mathrm{d}, \mathrm{A}}$ \\
acidity, $\left.{ }^{\circ} \mathrm{T}\right)$ & $0.3 \%$ & $77.58 \pm 1.05^{\mathrm{c}, \mathrm{D}}$ & $86.15 \pm 0.41^{\mathrm{b}, \mathrm{C}}$ & $91.42 \pm 0.36^{\mathrm{b}, \mathrm{AB}}$ & $89.01 \pm 2.27^{\mathrm{c}, \mathrm{BC}}$ & $94.33 \pm 0.61^{\mathrm{b}, \mathrm{A}}$ \\
& $0.5 \%$ & $83.39 \pm 0.37^{\mathrm{b}, \mathrm{D}}$ & $85.71 \pm 0.37^{\mathrm{b}, \mathrm{C}}$ & $91.36 \pm 1.06^{\mathrm{b}, \mathrm{B}}$ & $92.32 \pm 0.50^{\mathrm{b}, \mathrm{B}}$ & $96.92 \pm 1.03^{\mathrm{ab}, \mathrm{A}}$ \\
& $0.7 \%$ & $93.9 \pm 1.98^{\mathrm{a}, \mathrm{C}}$ & $97.86 \pm 0.94^{\mathrm{a}, \mathrm{BC}}$ & $100.64 \pm 3.28^{\mathrm{a}, \mathrm{AB}}$ & $102.28 \pm 0.12^{\mathrm{a}, \mathrm{A}}$ & $105.22 \pm 0.56^{\mathrm{a}, \mathrm{A}}$ \\
\hline
\end{tabular}

$*$ a, b, c, d, e Means in the same column with different superscripts significantly differ $(\mathrm{P}<0.05)$

* A, B, C, D, E Means in the same row with different superscripts among fermented milk drink samples significantly differ $(\mathrm{P}<0.05)$

* SD: Standard deviation

Table 4

Apparent viscosity of fermented milk drink samples

\begin{tabular}{cccccc}
\hline Samples & Day 0 & Day 7 & Day 14 & Day 21 & Day 28 \\
\hline K & $64.17 \pm 3.86^{\mathrm{e}, \mathrm{C}}$ & $702.83 \pm 3.01^{\mathrm{c}, \mathrm{B}}$ & $1023.33 \pm 17.74^{\mathrm{c}, \mathrm{A}}$ & $1095.83 \pm 80.01^{\mathrm{d}, \mathrm{A}}$ & $1003.33 \pm 147.95^{\mathrm{c}, \mathrm{BC}}$ \\
$\mathrm{A}$ & $131.20 \pm 1.06^{\mathrm{d}, \mathrm{C}}$ & $1284.33 \pm 73.05^{\mathrm{b}, \mathrm{A}}$ & $1211.83 \pm 32.04^{\mathrm{c}, \mathrm{A}}$ & $1322.5 \pm 49.94^{\mathrm{c}, \mathrm{A}}$ & $988.75 \pm 5.30^{\mathrm{c}, \mathrm{BC}}$ \\
$\mathrm{B}$ & $243.33 \pm 20.23^{\mathrm{c}, \mathrm{D}}$ & $1605 \pm 10.00^{\mathrm{a}, \mathrm{B}}$ & $2645 \pm 45.83^{\mathrm{b}, \mathrm{A}}$ & $1536.67 \pm 46.46^{\mathrm{b}, \mathrm{B}}$ & $1210.83 \pm 45.85^{\mathrm{bc}, \mathrm{A}}$ \\
$\mathrm{C}$ & $716.00 \pm 41.94^{\mathrm{b}, \mathrm{D}}$ & $1758.17 \pm 3.55^{\mathrm{a}, \mathrm{BC}}$ & $2958.33 \pm 315.29^{\mathrm{a}, \mathrm{A}}$ & $2070.83 \pm 5.20^{\mathrm{a}, \mathrm{B}}$ & $1446.67 \pm 52.70^{\mathrm{b}, \mathrm{C}}$ \\
D & $1861.25 \pm 15.91^{\mathrm{a}, \mathrm{AB}}$ & $1824.33 \pm 239.64^{\mathrm{a}, \mathrm{B}}$ & $3413.33 \pm 65.06^{\mathrm{a}, \mathrm{A}}$ & $1525.83 \pm 9.46^{\mathrm{b}, \mathrm{B}}$ & $1930 \pm 56.57^{\mathrm{a}, \mathrm{B}}$ \\
\hline
\end{tabular}

$* \mathrm{a}, \mathrm{b}, \mathrm{c}, \mathrm{d}$ Means in the same column with different superscripts significantly differ $(\mathrm{P}<0.05)$

* A, B, C, D Means in the same row with different superscripts among kefir samples significantly differ $(\mathrm{P}<0.05)$

* SD: Standard deviation 
The storage period could significantly affect the apparent viscosity of samples. For all the samples, the apparent viscosity showed a trend of rising first and falling then during storage period, the apparent viscosity was the highest on the $14^{\text {th }}$ day. Considering viscosity, it is best to fermented milk drink added with RB within 14 days.

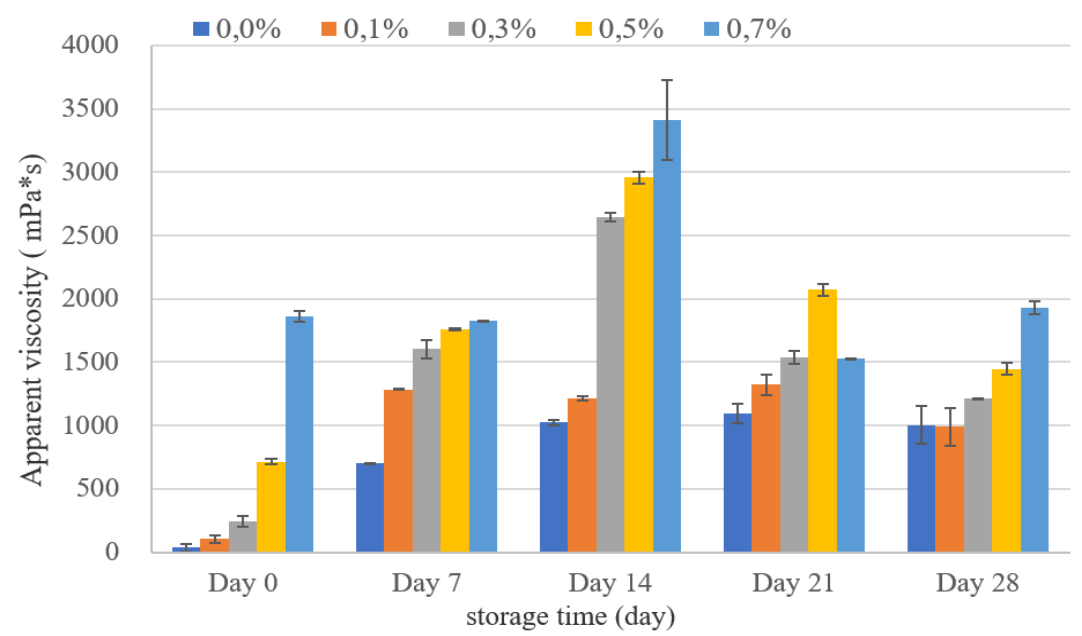

Fig. 3. Apparent viscosity of fermented milk drink samples during storage for 28 days $(n=3, \pm$ SD)

(a)

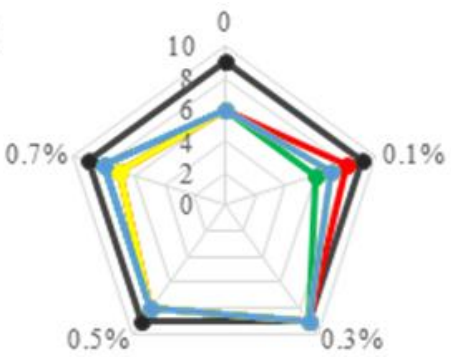

(c)

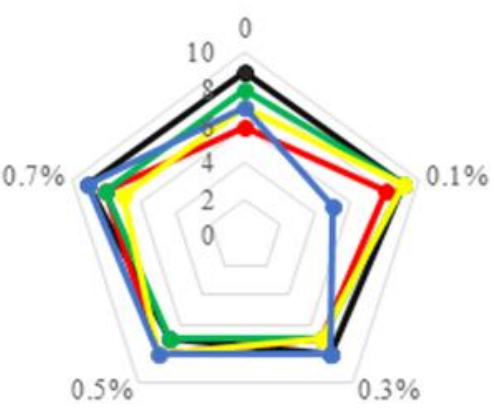

(b)

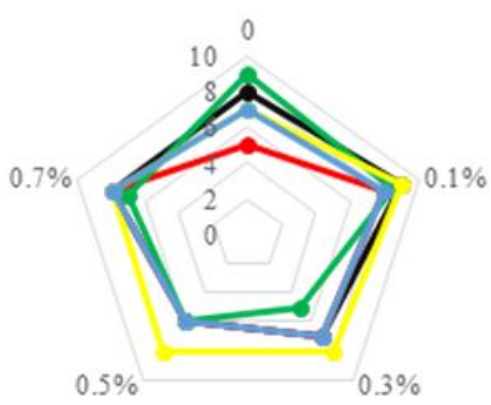

(d)

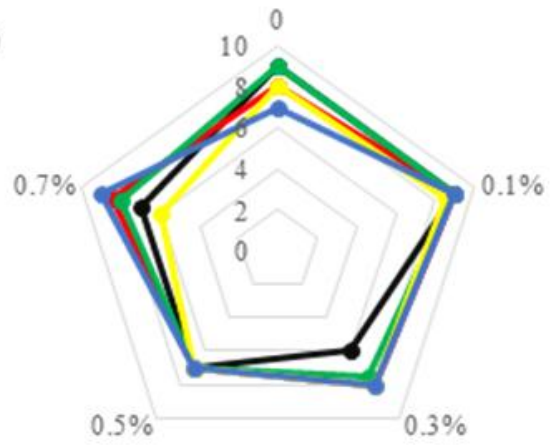

(e)

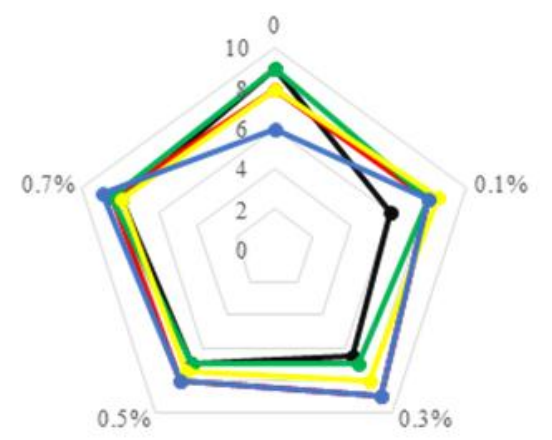

$\rightarrow$ color $\rightarrow$ flavor $\rightarrow$ texture $\rightarrow$ sour $\rightarrow$ consistency

Fig. 4. Sensory properties of fermented milk drink samples in 28 days (a) 0-day, (b) 7th day, (c) 14th day, (d) 21st day, (e) 28 th day 
The sensory characteristics of fermented milk drinks in 28 days were showed in figure 4. The introduction of RB significantly affected the sensory characteristics of fermented milk drinks $(\mathrm{P}<0.05)$. RB could increase the viscosity of fermented milk drink, because of the good WHC of dietary fiber and protein in RB. RB gave fermented milk drink its unique rice flavor, the more RB was added, the strong rice flavor was, but decrease of flavor acceptability of samples occurred when the adding amount of RB was up to $0.5 \%$. Meanwhile, the introduction of $\mathrm{RB}$ would separate whey, resulting in uneven texture and reducing product acceptability. While (Demirci et al., 2017) reported that all RB fortified fermented milk were assessed with lower values compared to plain samples, increasing proportion of $\mathrm{RB}$ led to a lower acceptability of samples (Goncu, 2017) reported that dietary fiber addition positively influenced taste and aroma, consistency and general acceptability scores up to at a rate of $0.5 \%$, because of better mouth thickness and pleasant aroma of them.

The higher fiber concentration $(1 \%)$ caused the lower sensory scores. The storage period made significantly effect on the sensory quality of fermented milk drink ( $\mathrm{P}<0.05$ ). Totally speaking, the acceptability of fermented milk drink was the highest when $0.1 \%$ RB was added, and $0.5 \% \mathrm{RB}$ added fermented milk drinks had the lowest sensory scores. The introduction of RB into fermented milk drink lead to whey separation, rough texture, although it can improve the viscosity, and rich the flavor of fermented milk drink. The problem of whey separation should be solved if RB introduced into fermented milk drink. In general, the acceptability of fermented milk drink was highest when RB was added as $0.1 \%$.

\section{Discussion}

$\mathrm{RB}$ is a kind of industrial and agricultural waste which was rich in dietary fiber $(28.57 \%)$, fat $(21.56 \%)$ and protein $(11.18 \%)$. There are some advantages of the introduction of RB into fermented milk drink. Results showed that the introduction of $\mathrm{RB}$ could increase the $\mathrm{pH}$ value and decrease the acidity value of fermented milk drink significantly $(\mathrm{P}<0.05)$, which may partially be attributed to the protein and fiber in $\mathrm{RB}$. The introduction of RB could increase the apparent viscosity of fermented milk drink significantly $(\mathrm{P}<0.05)$, the more $\mathrm{RB}$ was added, the higher the apparent viscosity was. In terms of sensory, the introduction of RB would increase the thickness and rich the flavor of fermented milk drink, lead to whey layered and rough taste. The more RB was added, the greater the negative impact was, in terms of sensory, the appropriate ratio of $\mathrm{RB}$ was $0.1 \%$.

The storage period could influence the $\mathrm{pH}$, acidity and apparent viscosity significantly $(\mathrm{P}<0.05)$. Storage period could increase the $\mathrm{pH}$ and decreased the acidity significantly $(\mathrm{P}<0.05)$ for the post-fermentation. In terms of $\mathrm{pH}$ and acidity, it was best to be eaten within 21 days for fermented milk drink. Storage period influenced the apparent viscosity of fermented milk drink significantly $(\mathrm{P}<0.05)$, the apparent viscosity increased at the beginning and decreased then with the prolonging of storage period, samples had the highest apparent viscosity on the 14th day. In terms of apparent viscosity, it was best to be eaten within 14 days.

\section{Conclusion}

Overall, the best introduction amount of $\mathrm{RB}$ was $0.1 \%$, it was best for fermented milk drink added with RB to be eaten within 14 days. On the basis of the physical-chemical, rheological and sensory properties study, results suggest that $\mathrm{RB}$ could be potentially considered as a source of ingredient for fermented milk drink supplementation.

\section{Acknowledgments}

Thanks to Professor Yanhe Luo for his financial support. The article was fund by school level project, Hezhou University, project name: A series of food made by waterchestnut with low GI, project number: 209200004.

The article was fund by National Key R\&D Program of China (2018YFD0901003).

\section{References}

Ahmed, Z., Wang, Y., Ahmad, A., Khan, S. T., Nisa, M., Ahmad, H., \& Afreen, A. (2013). Kefir and Health: A Contemporary Perspective. Critical Reviews in Food Science \& Nutrition, 53(5), 422-434. doi: 10.1080/10408398.2010.540360.

AOAC (2000). Methods of analysis (17th ed.). In. Washington DC: Association of Official Analytical Chemists.

Chen, C.-H., Yang, Y.-H., Shen, C.-T., Lai, S.-M., Chang, C.-M. J., \& Shieh, C.-J. (2011). Recovery of vitamins B from supercritical carbon dioxide-defatted rice bran powder using ultrasound water extraction. Journal of the Taiwan Institute of Chemical Engineers, 42(1), 124-128. doi: 10.1016/j.jtice.2010.04.011.

Chifiriuc, M. C., Cioaca, A. B., \& Lazar, V. (2011). In vitro assay of the antimicrobial activity of kephir against bacterial and fungal strains. Anaerobe, 17(6), 433-435. doi: 10.1016/j.anaerobe.2011.04.020.

Choi, Y.-S., Choi, J.-H., Han, D.-J., Kim, H.-Y., Lee, M.A., Jeong, J.-Y., Chung, H.-J., \& Kim, C.-J. (2010). Effects of replacing pork back fat with vegetable oils and rice bran fiber on the quality of reduced-fat frankfurters. Meat Science, 84(3), 557-563. doi: 10.1016/j.meatsci.2009.10.012.

Demirci, T., Aktaş, K., Sözeri, D., Öztürk, H. İ., \& Akın, N. (2017). Rice bran improve probiotic viability in yoghurt and provide added antioxidative benefits. Journal of Functional Foods, 36, 396-403. doi: 10.1016/j.jff.2017.07.019.

Devarajan, S., Singh, R., Chatterjee, B., Zhang, B., \& Ali, A. (2016). A blend of sesame oil and rice bran oil lowers blood pressure and improves the lipid profile in mild-tomoderate hypertensive patients. Journal of Clinical Lipidology, 10(2), 339-349. doi: 10.1016/j.jacl.2015.12.011.

Ertekin, B., \& Guzel-Seydim, Z. B. (2010). Effect of fat replacers on kefir quality. Journal of the Science of Food and Agriculture, 90(4), 543-548. doi: 10.1002/jsfa.3855. 
Goncu, B. (2017). Some properties of kefir enriched with apple and lemon fiber. Mljekarstvo, 67(3), 208-216. doi: 10.15567/mljekarstvo.2017.0305.

Guzel-Seydim, Z. B., Kok-Tas, T., Greene, A. K., \& Seydim, A. C. (2011). Review: Functional Properties of Kefir. Critical Reviews in Food Science \& Nutrition, 51(3), 261-268. doi: 10.1080/10408390903579029.

Hu, W., Wells, J. H., Shin, T. S., \& Godber, J. S. (1996). Comparison of isopropanol and hexane for extraction of vitamin $\mathrm{E}$ and oryzanols from stabilized rice bran. Journal of the American Oil Chemists' Society, 73(12), 1653-1656. doi: 10.1007/BF02517967.

Iraporda, C., Romanin, D. E., Rumbo, M., Garrote, G. L., \& Abraham, A. G. (2014). The role of lactate on the immunomodulatory properties of the nonbacterial fraction of kefir. Food Research International, 62(8), 247-253. doi: 10.1080/10408398.2010.540360.

ISO (2014). Milk and milk products - Determination of nitrogen content - Part 1: Kjeldahl principle and crude protein calculation. In. Switzerland.

Jia, M., Chen, J., Liu, X., Xie, M., Nie, S., Chen, Y., Xie, J., \& Yu, Q. (2019). Structural characteristics and functional properties of soluble dietary fiber from defatted rice bran obtained through Trichoderma viride fermentation. Food Hydrocolloids, 94, 468474. doi: 10.1016/j.foodhyd.2019.03.047.

Kim, D., Jeong, D., Kang, I., Kim, H., Song, K., \& Seo, K. (2017). Dual function of Lactobacillus kefiri DH5 in preventing high-fat-diet-induced obesity: direct reduction of cholesterol and upregulation of PPAR- $\alpha$ in adipose tissue. Molecular Nutrition \& Food Research, 61(11). doi: 10.1002/mnfr.201700252.

Leite, A. M. O., Miguel, M. A. L., Peixoto, R. S., RuasMadiedo, P., Paschoalin, V. M. F., Mayo, B., \&Delgado, S. (2015). Probiotic potential of selected lactic acid bacteria strains isolated from Brazilian kefir grains. Journal of Dairy Science, 98(6), 3622-3632. doi: 10.3168/jds.2014-9265.

Li, S.-C., Chou, T.-C., \& Shih, C.-K. (2011). Effects of brown rice, rice bran, and polished rice on colon carcinogenesis in rats. Food Research International, 44(1), 209-216. doi: 10.1016/j.foodres.2010.10.034.

Patil, S. S., Kar, A., \& Mohapatra, D. (2016). Stabilization of rice bran using microwave: Process optimization and storage studies. Food and Bioproducts Processing, 99, 204-211. doi: 10.1016/j.fbp.2016.05.002.

Perez-Ternero, C., Alvarez de Sotomayor, M., \& Herrera, M. D. (2017). Contribution of ferulic acid, $\gamma$-oryzanol and tocotrienols to the cardiometabolic protective effects of rice bran. Journal of Functional Foods, 32, 58-71. doi: 10.1016/j.jff.2017.02.014.

Phongthai, S., Lim, S.-T., \& Rawdkuen, S. (2016). Optimization of microwave-assisted extraction of rice bran pro- tein and its hydrolysates properties. Journal of Cereal Science, 70, 146-154. doi: 10.1016/j.jcs.2016.06.001.

Prestes, D. N., Spessato, A., Talhamento, A., Gularte, M. A., Schirmer, M. A., Vanier, N. L., \& Rombaldi, C. V. (2019). The addition of defatted rice bran to malted rice improves the quality of rice beer. LWT, 112, 108262. doi: 10.1016/j.1wt.2019.108262.

Shah, B. R., Li, B., Sabbah, H. A., Xu, W., \& Mraz, J. (2020). Effects of prebiotic dietary fibers and probiotics on human health: With special focus on recent advancement in their encapsulated formulations. Trends in Food Science \& Technology, 102, 178-192. doi: 10.1016/j.tifs.2020.06.010.

Soares, J. F., Dal Prá, V., de Souza, M., Lunelli, F. C., Abaide, E., da Silva, J. R. F., Kuhn, R. C., Martínez, J., \& Mazutti, M. A. (2016). Extraction of rice bran oil using supercritical $\mathrm{CO} 2$ and compressed liquefied petroleum gas. Journal of Food Engineering, 170, 58-63. doi: 10.1016/j.jfoodeng.2015.09.016.

Tabaraki, R., \& Nateghi, A. (2011). Optimization of ultrasonic-assisted extraction of natural antioxidants from rice bran using response surface methodology. Ultrasonics Sonochemistry, 18(6), 1279-1286. doi: 10.1016/j.ultsonch.2011.05.004.

Trevisani Juchen, P., Nolasco Araujo, M., Hamerski, F., Corazza, M. L., \& Pedersen Voll, F. A. (2019). Extraction of parboiled rice bran oil with supercritical $\mathrm{CO} 2$ and ethanol as co-solvent: Kinetics and characterization. Industrial Crops and Products, 139, 111506. doi: 10.1016/j.indcrop.2019.111506.

Tuncel, N. B., Y1lmaz, N., Kocabiyık, H., \& Uygur, A. (2014). The effect of infrared stabilized rice bran substitution on physicochemical and sensory properties of pan breads: Part I. Journal of Cereal Science, 59(2), 155-161. doi: 10.1016/j.jcs.2013.12.003.

Wu, W., Hu, J., Gao, H., Chen, H., Fang, X., Mu, H., Han, Y., \& Liu, R. (2020). The potential cholesterol-lowering and prebiotic effects of bamboo shoot dietary fibers and their structural characteristics. Food Chemistry, 332, 127372. doi: 10.1016/j.foodchem.2020.127372.

Wyk, J. V., Witthuhn, R. C., \& Britz, T. J. (2011). Optimisation of vitamin $\mathrm{B}<\mathrm{sub}>12</ \mathrm{sub}>$ and folate production by $<\mathrm{i}>$ Propionibacterium freudenreichii $</ \mathrm{i}>$ strains in kefir. International Dairy Journal, 21(2), 69-74. http://www.wanfangdata.com.cn/details/detail.do?_type =perio\&id=b5f404c1b34b39179fbc9a7990681cb1.

Zaharova, L. (2014). Development and Introduction of New Dairy Technologies. Foods and Raw Materials, 2(2), 68-74. doi: 10.12737/5462.

Zullaikah, S., Melwita, E., \& Ju, Y.-H. (2009). Isolation of oryzanol from crude rice bran oil. Bioresource Technology, 100(1), 299-302. doi: 10.1016/j.biortech.2008.06.008. 